\title{
Az akut canagliflozinkezelés kivédi a miokardiális iszkémia-reperfúziós károsodást patkánymodellen
}

\author{
Sayour Alex Ali1,2, Ruppert Mihály,2, Oláh Attila1, Benke Kálmán', Benkő Rita3, \\ Horváth Eszter Mária ${ }^{3}$, Korkmaz-Icöz Sevil2, Loganathan Sivakkanan², \\ Karck Matthias², Merkely Béla', Szabó Gábor², Radovits Tamás'
}

\author{
${ }^{1}$ Semmelweis Egyetem, Városmajori Szív- és Érgyógyászati Klinika, Budapest \\ ${ }^{2}$ Ruprecht-Karls Egyetem, Szívsebészeti Klinika, Heidelberg, Németország \\ ${ }^{3}$ Semmelweis Egyetem, Élettani Intézet, Budapest \\ Levelezési cím: \\ Dr. Sayour Alex Ali, Semmelweis Egyetem, Városmajori Szív- és Érgyógyászati Klinika, Kísérleti Kutató Laboratórium \\ 1122 Budapest, Városmajor u. 68. E-mail: alexali.sayour@gmail.com
}

Bevezetés: A nátrium-glükóz-kotranszporter-2- (SGLT2) inhibitor canagliflozin csökkenti a 2-es típusú diabéteszes betegekben a súlyos kardiovaszkuláris események előfordulását. Ez direkt kardiovaszkuláris hatásra utalhat, amely jelenleg nem teljesen tisztázott. Célul tűztük ki a canagliflozin kardiovaszkuláris hatásainak karakterizálását miokardiális iszkémia-reperfúziós károsodás patkánymodelljén.

Módszerek: Nem diabéteszes patkányokban áloperációt, vagy az elülső leszálló koronária ideiglenes okklúzióját végeztük 30 percig, amelyet 120 perc reperfúzió követett. A vivőanyag vagy canagliflozin egyetlen intravénás bólusként került beadásra az iszkémia kialakulását követő 5. percben. Meghatároztuk az infarktus területét, a szérum troponin-T-szintjét és vizsgáltuk a bal kamra (BK) funkcióját. Fehérje-, mRNS-expressziós és immunhisztokémiai vizsgálatokat végeztünk BK-i myocardiummintákon. Aortagyürükön végzett in vitro miográfos mérésekkel vizsgáltuk a canagliflozin vaszkuláris funkcióra kifejtett hatását.

Eredmények: Canagliflozinnal történő akut kezelés csökkentette a miokardiális infarktus területét $(42,5 \pm 2,9 \%$ vs. $59,3 \pm 4,2 \%, p=0,006)$ és szérum troponin-T-szintjét a vivőanyaghoz képest. A canagliflozin enyhítette az iszkémia-reperfúziós (IR) károsodást követő BK-i szisztolés és diasztolés diszfunkciót. A kezelés fokozta az adenozin-monofoszfát-aktiválta protein-kináz (AMPK), Akt és endotheliális nitrogén-monoxid-szintáz (eNOS) foszforilációját, valamint csökkentette az apoptotikus (Bax/Bcl-2 arány) és oxidatív stressz-markerek miokardiális expresszióját. A kezelt szívekben csökkent a lipidperoxidáció mértéke. A canagliflozinnal való előkezelés fokozta az endothelfüggő vazorelaxációt. Következtetések: Az intravénásan beadott SGLT2-inhibitor canagliflozin csökkenti a miokardiális IR-károsodást függetlenül az antidiabetikus hatástól és fokozza az endothelfüggő vazorelaxációt. Eredményeink hozzájárulhatnak a canagliflozin klinikai vizsgálatokban megfigyelt kardiovaszkuláris védő hatásának megértéséhez.

Kulcsszavak: nátrium-glükóz-kotranszporter-2-inhibitor, miokardiális iszkémia-reperfúziós károsodás, kardioprotekció

Készült Sayour, et al. J Transl Med 2019; 17: 127. közleményének felhasználásával a Springer Nature Kiadó írásos engedélyével.

A kézirat 2020. 04. 14-én érkezett a szerkesztőségbe, 2020. 06. 19-én került elfogadásra. 


\section{Acute canagliflozin treatment protects against myocardial ischemia-reperfusion injury in a rat model}

Introduction: The sodium-glucose cotransporter-2 (SGLT2) inhibitor canagliflozin reduces major cardiovascular events in patients with type 2 diabetes. This suggests that there is a direct cardioprotective effect, which is incompletely understood. We aimed to characterize the cardiovascular effects of canagliflozin in a rat model of myocardial ischemiareperfusion injury.

Methods: Non-diabetic rats underwent sham operation or left anterior descending coronary artery occlusion for 30 minutes, followed by 120 minutes of reperfusion. Vehicle or canagliflozin was administered as a single intravenous bolus in the $5^{\text {th }}$ minute of ischemia. We measured infarct size, serum troponin $T$ and left ventricular (LV) function. Protein and mRNA expression, as well as immunohistochemical measurements were carried out on LV myocardial samples. We investigated the vascular effect of canagliflozin with in vitro myograph experiments.

Results: Acute treatment with canagliflozin reduced myocardial infarct size $(42.5 \pm 2.9 \%$ vs. $59.3 \pm 4.2 \%, P=0.006)$ and serum troponin T levels compared to vehicle treatment. Canagliflozin alleviated myocardial ischemia-reperfusion (IR) injury-associated LV systolic and diastolic dysfunction. The treatment increased phosphorylation of adenosine monophosphate-activated protein kinase (AMPK), Akt and endothelial nitric-oxide synthase (eNOS), while reduced the myocardial expression of apoptotic (Bax/Bcl-2 ratio) and oxidative stress-related genes. Lipid peroxidation decreased in treated hearts. Preincubation with canagliflozin enhanced endothelium-dependent vasorelaxation.

Conclusions: Intravenously administered SGLT2 inhibitor canagliflozin reduces myocardial IR injury independently of antidiabetic action and enhances endothelium-dependent vasorelaxation. Our results might contribute to the understanding of the possible direct cardioprotective effect of canagliflozin seen in clinical trials.

Keywords: sodium-glucose cotransporter-2 inhibitor, myocardial ischemia-reperfusion injury, cardioprotection

\section{Bevezetés}

A nátrium-glükóz-kotranszporter-2- (SGLT2) inhibitorok újfajta antidiabetikus szerek, amelyeket világszerte egyre növekvő számban alkalmaznak 2-es típusú diabéteszes betegeknél. Az EMPA-REG OUTCOME (1) klinikai vizsgálat kimutatta, hogy az SGLT2-gátló empagliflozin jelentősen csökkentette a major kardiovaszkuláris események kockázatát a placebóhoz képest diabéteszes betegekben. Ezt megerősítette a CANVAS klinikai tanulmány (2), amelyben az SGLT2-gátló canagliflozinnak hasonló szignifikáns hatása volt a kompozit végpontra magas kardiovaszkuláris rizikójú cukorbetegekben. A szívelégtelenség miatti hospitalizáció mintegy harmadával csökkent (2), amely csökkenés a már meglévő szívelégtelenséggel küzdő betegek körében még nagyobb mértékű volt (3). Érdekes módon az SGLT2-gátlóval kezelt betegek ugyanakkora eséllyel szenvedtek el miokardiális infarktust, mint a placebokezeltek, azonban nagyobb eséllyel élték azt túl (2). Ezek szerint a canagliflozin direkt kardiovaszkuláris védő hatást fejthet ki függetlenül az antidiabetikus hatástól, amelynek mechanizmusa még nem teljesen tisztázott $(4,5)$.

Kísérletes tanulmányok szerint a canagliflozin nagymértékben aktiválja az adenozin-monofoszfát-aktiválta protein-kinázt (AMPK) in vitro (6), közvetlenül gátolja a nátrium-hidrogén kicserélő transzportert (NHE) nem diabéteszes, egészséges szívekben (7), és direkt vazorelaxáns hatást fejt ki diabéteszes állapotban (8,
9). Nem teljesen ismert, hogy a canagliflozinkezelésnek van-e közvetlen, az antidiabetikus hatástól független szív- és érrendszeri hatása. Ezért jelen kutatásban célul tűztük ki a canagliflozinkezelés kardiovaszkuláris hatásainak vizsgálatát egészséges és akut miokardiális infarktuson átesett patkányokban.

\section{Módszerek}

\section{Kísérleti állatok, protokollok}

Vizsgálatainkat a kísérleti állatok tartásáról és felhasználásáról szóló nemzetközi szabályoknak (Guide for the Care and Use of Laboratory Animals, US National Institutes of Health 1996; 85-23.) megfelelően végeztük. Nem diabéteszes, hím Sprague-Dawley (SD) patkányainkat (Janvier Labs, Franciaország) standard laboratóriumi körülmények között tartottuk az akklimatizáció során.

In vivo tanulmányunkban az IR-károsodást az elülső leszálló koronária (LAD) ideiglenes okklúziójával váltottuk ki. Ennek során nátrium-pentobarbitállal altatott, mechanikusan lélegeztetett, fütőpadon elhelyezett állatokban felkerestük a 4. bordaköz feltárásával a LAD-ot, azt standard magasságban aláöltve 30 percig okkludáltuk (iszkémia szakasza) elektrokardiográfiás monitorozás mellett. Majd a leszorítást felengedtük, így kezdetét vette a 120 perc reperfúzió. Kontrollállatokban áloperációt (sham) végeztünk, amely során a LAD-ot aláöltöttük, de nem okkludáltuk (nincs IR-károsodás). 
A vivőanyagot vagy canagliflozint $(3 \mu \mathrm{g} / \mathrm{kg}$, klinikailag releváns dózis [10]) a LAD leszorítását (illetve áloperált állatok esetében $L A D$ aláöltését) követő 5 . percben intravénás bólusként adtuk be. Ezzel egy klinikailag releváns szituációt akartunk modellezni, amely során az akut infarktust szenvedő beteg a katéteres érmegnyitás (reperfúzió) előtt kap gyógyszeres kezelést. Erre a canagliflozin viszonylag hosszú felezési ideje ( 9,5 óra) adott lehetőséget.

A tanulmány első felében (1. A ábra) az IR-károsodást szenvedett vivőanyaggal (IRI, $n=7$ ) vagy canagliflozinnal (IRI + cana, $n=7)$ kezelt állatokban Evans kék és trifenil-tetrazólium-klorid kettősfestéssel vizualizáltuk a rizikóterületet (ún. area at risk) és ezen belül az infarktus területét, amelyet előbbire normalizáltunk planimetriás kielemzéssel. Továbbá meghatároztuk a szérum troponin-T-szintjét. Csoportonként 1-1 állat pusztult el az iszkémia során kialakuló végzetes szívritmuszavar következtében. A feltüntetett elemszámok a végleges feldolgozásig túlélő állatok számát adják meg.

A tanulmány második felében (1. B ábra) az IR-károsodáson (jelölés: IRI) vagy áloperáción (jelölés: sham) átesett, vivőanyaggal vagy canagliflozinnal kezelt állatokban a bal kamrai (BK) szívfunkciót kutatócsoportunk által korábban leírt módon (11) nyomás-térfogat (PV) analízissel vizsgáltuk az alábbi csoportoknak megfelelően: sham + vivőanyag $(n=7)$, sham + canagliflozin $(n=7), \quad I R I+$ vivőanyag $(n=9)$, és IRI + canagliflozin $(n=10)$. Ennek során egy $2 F r$ es nyomás-konduktancia mikrokatétert vezettünk a BK-ba. Regisztráltuk a szívfrekvenciát, végszisztolés nyomást, BK-i szisztolés nyomásnövekedés maximális sebességét $\left(\mathrm{dP} / \mathrm{dt}_{\max }\right)$ és a BK-i relaxáció időkonstansát $\left(\mathrm{Tau}_{\text {Weiss }}\right)$. A BK-i funkcionális regenerációt a szívfrekvencia és végszisztolés nyomás szorzatával (ún. rate-pressure product, RPP) jellemeztük. Változó előterhelés mellett regisztráltuk a végszisztolés $P V$ összefüggés meredekségét (ESPVR), a verőmunka-végdiasztolés térfogat összefüggés meredekségét (ún. preload recruitable stroke work, PRSW), végdiasztolés $P V$-összefüggés meredekségét (EDPVR) és a mechanikus hatásfokot. A ventrikulo-arteriális kapcsolást (VAC) az artériás elasztancia $\left(E_{a}\right)$ és ESPVR hányadosaként határoztuk meg. A PV-méréseket követően vért vettünk az állatoktól és konzerváltuk a szíveket további molekuláris és immunhisztokémiai mérésekre. A vivőanyaggal kezelt csoportban 3, míg a canagliflozinnal kezelt csoportban 2 állat pusztult el az iszkémia során kialakuló végzetes szívritmuszavar következtében. A feltüntetett elemszámok a végleges feldolgozásig túlélő állatok számát adják meg.

\section{Western blot}

Az izolált BK-i miokardiális fehérjéket gélelektroforézissel választottuk szét majd membránokra blottoltuk, amelyeket az alábbi targetek elleni primer antitestekkel reagáltattunk: teljes Akt, foszforilált Akt
(p-Akt), teljes AMPK, p-AMPK, teljes acetil-koenzimA-karboxiláz (ACC), p-ACC, teljes endotheliális nitrogén-monoxid-szintáz (eNOS), p-eNOS, B-cell leukémia/lymphoma 2 (Bcl-2), és Bcl-2 asszociált protein $x$ (Bax). A blotokat kemilumineszcens módszerrel hívtuk elő, amelyeket denzitometriailag elemeztünk.

\section{Génexpressziós vizsgálat}

A myocardium teljes RNS-tartalmát izoláltuk, majd reverz transzkripciót követően a cDNS-mintákból kvantitatív valósidejü polimeráz láncreakció (qRT-PCR) segítségével az alábbi gének expresszióját vizsgáltuk: Bax, Bcl-2, kataláz, szuperoxid-dizmutáz (SOD2), nikotinamid adenin-dinukleotid-foszfát (NADPH) oxidáz p47 alegység ( $\left.\mathrm{p} 47^{\mathrm{phox}}\right)$. A génexpressziós adatokat a riboszomális protein L27-re (RPL27) normalizáltuk.

\section{Immunhisztokémia}

Paraformaldehid (4\%) fixációt majd paraffinos beágyazást követően a BK-i izomszövet metszeteken 4-hidroxinonenál (HNE) elleni antitestfestéssel vizsgáltuk a lipidperoxidáció mértékét fénymikroszkóp segítségével. Százszoros nagyítás mellett a BK-i digitális metszetek HNE pozitivitását szoftverrel határoztuk meg. A pozitív terület nagyságát a teljes területre normalizálva fejeztük ki.

\section{Szérum- és vizeletmérések}

Az állatoktól nyert szérum- és vizeletmintákon meghatároztunk vese- és májfunkciós paramétereket.

\section{In vitro szervfürdős kísérletek}

In vitro miográfos kísérleteinket a korábban leírtaknak megfelelően végeztük (12). Az egészséges, nem diabéteszes patkányokból nyert hasi aortaszakaszokat óvatos preparálást követően speciális kialakítású fémhorgokra helyeztük Krebs-oldatot tartalmazó szervfürdős kamrákban. $A z$ izometriás kontrakciókat migráfos erőmérő transzducer-rendszer segítségével regisztráltuk és digitalizáltuk szoftveres kielemzés céljából. Az aortagyűrüket vivőanyaggal vagy canagliflozinnal (10 $\mu \mathrm{M}$, klinikailag releváns plazmakoncentráció) (10) előinkubáltuk 30 percig (n=10 aortagyürü csoportonként). Kimosást és farmakológiai érösszehúzást követően meghatároztuk az acetil-kolin (ACh) fokozatosan növelt dózisára adott endothelfüggő vazorelaxációt, illetve a nátrium-nitroprusszid (SNP) általi endothelfüggetlen vazorelaxációt. Szigmoidális összefüggéssel határoztuk meg a fél-maximális koncentrációkat $\left(\mathrm{EC}_{50}\right)$ és a vazodilatátorok iránti szenzitivitást $\left(\mathrm{pD}_{2}=-\log \mathrm{EC}_{50}\right)$. A maximális vazorelaxációt $\left(R_{\max }\right)$ a maximális kontrakció százalékaként tüntettük fel.

\section{Statisztikai elemzés}

$\mathrm{Az}$ adatokat átlag $\pm S E M$ formájában adtuk meg. Két csoport esetén párosítatlan t-tesztet, míg négy csoport esetén kétutas varianciaanalízist (ANOVA) végeztünk 

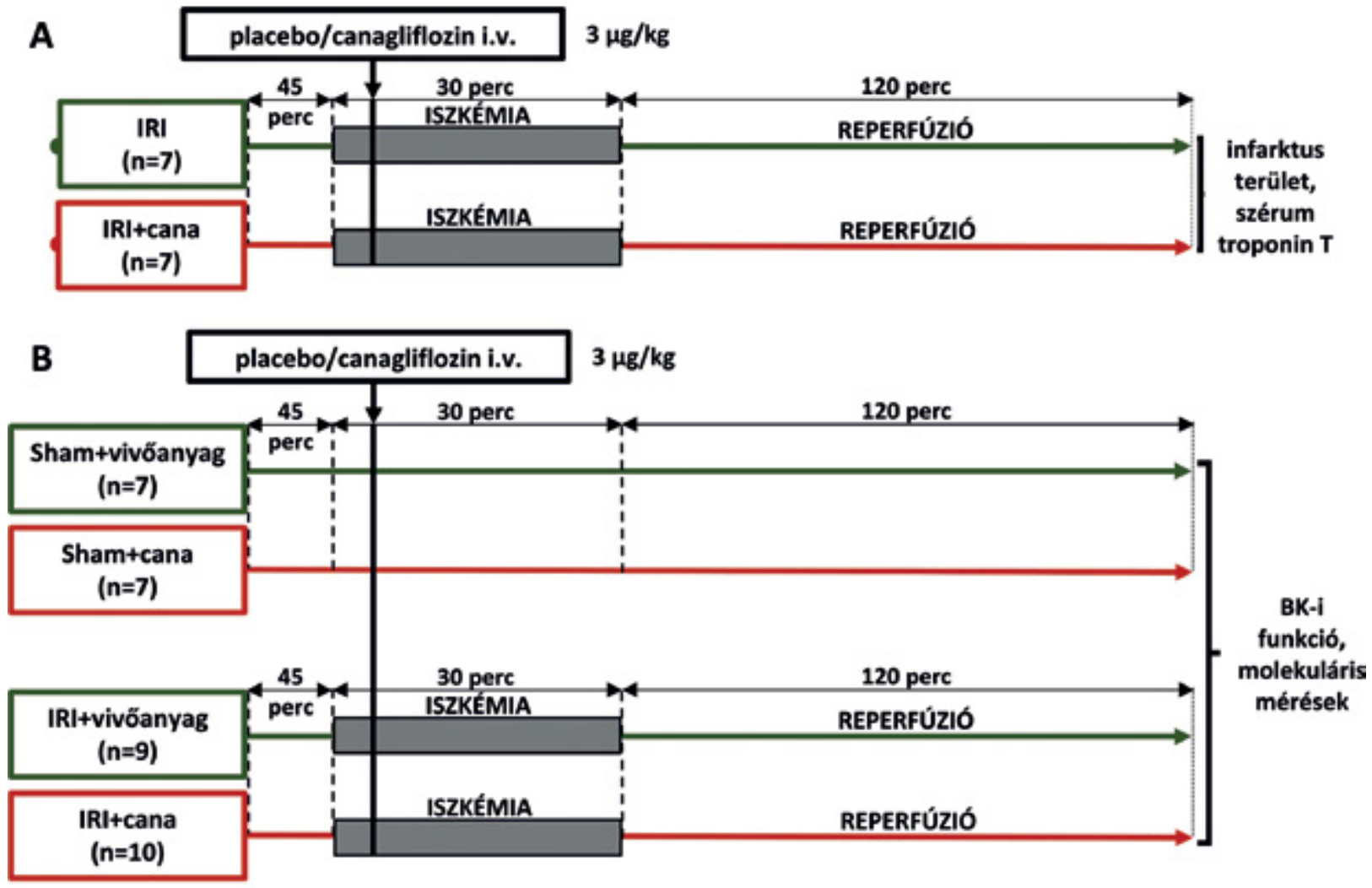

C
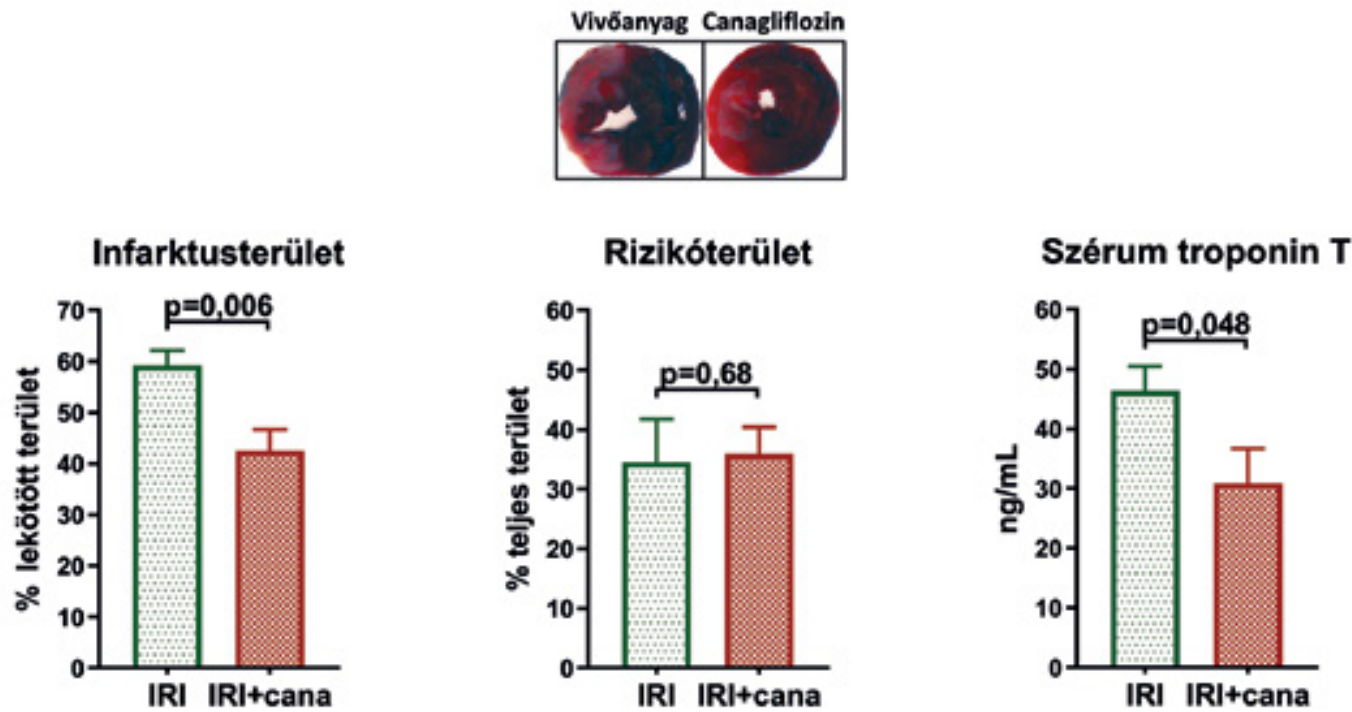

1. ÁBRA. Kísérleti protokoll, miokardiális infarktusterület és szérum-troponin-T. A: Kísérlet első fázisa, amely során infarktusos állatokban vizsgáltuk a canagliflozin hatását vivőanyaggal szemben. B: A kísérlet második fázisa, amely során áloperált („sham”) és infarktusos állatokban vizsgáltuk a canagliflozin balkamra- (BK) funkcióra és molekuláris célpontokra kifejtett hatását vivőanyaggal szemben. C: A kísérlet első fázisának eredményei: vivőanyaggal (IRI, n=7) és canagliflozinnal (IRI + cana, n=7) kezelt szívek infarktusának területe a rizikóterületre normalizálva, illetve a rizikóterület nagysága a teljes kamrai területre normalizálva látható

az alábbi két faktorral és azoknak megfelelő hipotézisteszteléssel: IR-károsodás $\left(p_{I R I}\right)$ és canagliflozinkezelés ( $\left.p_{\text {CANA }}\right)$, illetve ezek interakciója $\left(p_{\text {int }}\right)$. ANOVA-t követően Tukey post-hoc teszttel vizsgáltuk a csoportok közötti különbségeket. $A p<0,05$ értéket tekintettük statisztikailag szignifikánsnak.

\section{Eredmények}

A canagliflozin csökkentette a miokardiális infarktus területét

Egyetlen intravénás canagliflozinbólus 30\%-kal csökkentette az infarktus területét $(42,5 \pm 2,9 \%$ vs. $59,3 \pm 4,2 \%, p=0,006)$ és a szérum-troponin-T-szintet a 
vivőanyaggal kezeltekhez képest. Az okklúziótól disztálisan lévő rizikóterület nagysága megegyezett a két csoport között (1. C ábra).

\section{A canagliflozin enyhítette az IR-károsodást kö-} vetó BK-i szisztolés és diasztolés diszfunkciót A canagliflozin a szívfrekvencia befolyásolása nélkül elősegítette az IR-károsodást követő BK-i funkcionális felépülést (megnövekedett RPP-érték) és enyhítette a szisztolés diszfunkciót a megtartott $B K-i$ végszisztolés nyomás és $\mathrm{dP} / \mathrm{dt}_{\max }$ szerint (2. $A$ ábra), amelyek közül előbbi kettő IR specifikus hatásnak adódott $\left(p_{\mathrm{int}}=0,007\right)$. A terheléstöl független, érzékeny kontraktilitás paraméterek, mint az ESPVR (2. C ábra) és PRSW (2. E ábra) jelentős $(p<0,05)$ csökkenését figyeltük meg az áloperált állatokhoz képest infarktusban. Az infarktusos állatokban canagliflozinkezelés hatására az ESPVR meg- tartott volt, a PRSW szignifikánsan $(p=0,010)$ javult a vivőanyaghoz képest, amely IR-károsodásra specifikus hatás volt $\left(p_{\text {int }}=0,013\right)$ (2.C és $E$ ábra).

A TauWeiss, amely az aktív relaxáció érzékeny paramétere, jelentősen $(p=0,027)$ megnyúlt a vivőanyaggal kezelt infarktusos patkányokban, amely súlyosan csökkent diasztolés funkciót tükröz (2.F ábra). A canagliflozinkezelés azonban ezt megelőzte. Az EDPVR (BK-i falmerevségmarker) értéke erős növekvő tendenciát mutatott $(p=0,057)$ a vivőanyaggal kezelt infarktusos egyedekben, de a canagliflozinnal kezeltekben a kontrollal összehasonlítható szinten maradt (2. D ábra).

IR-károsodást követően a vivőanyaggal kezelt infarktusos patkányokban a VAC jelentős $(p=0,018)$ károsodását találtuk, amit canagliflozinkezelés kivédett $(p=0,022)$ (2.G ábra), és optimalizálta a BK-i mechanikus hatásfokot (2.G ábra).
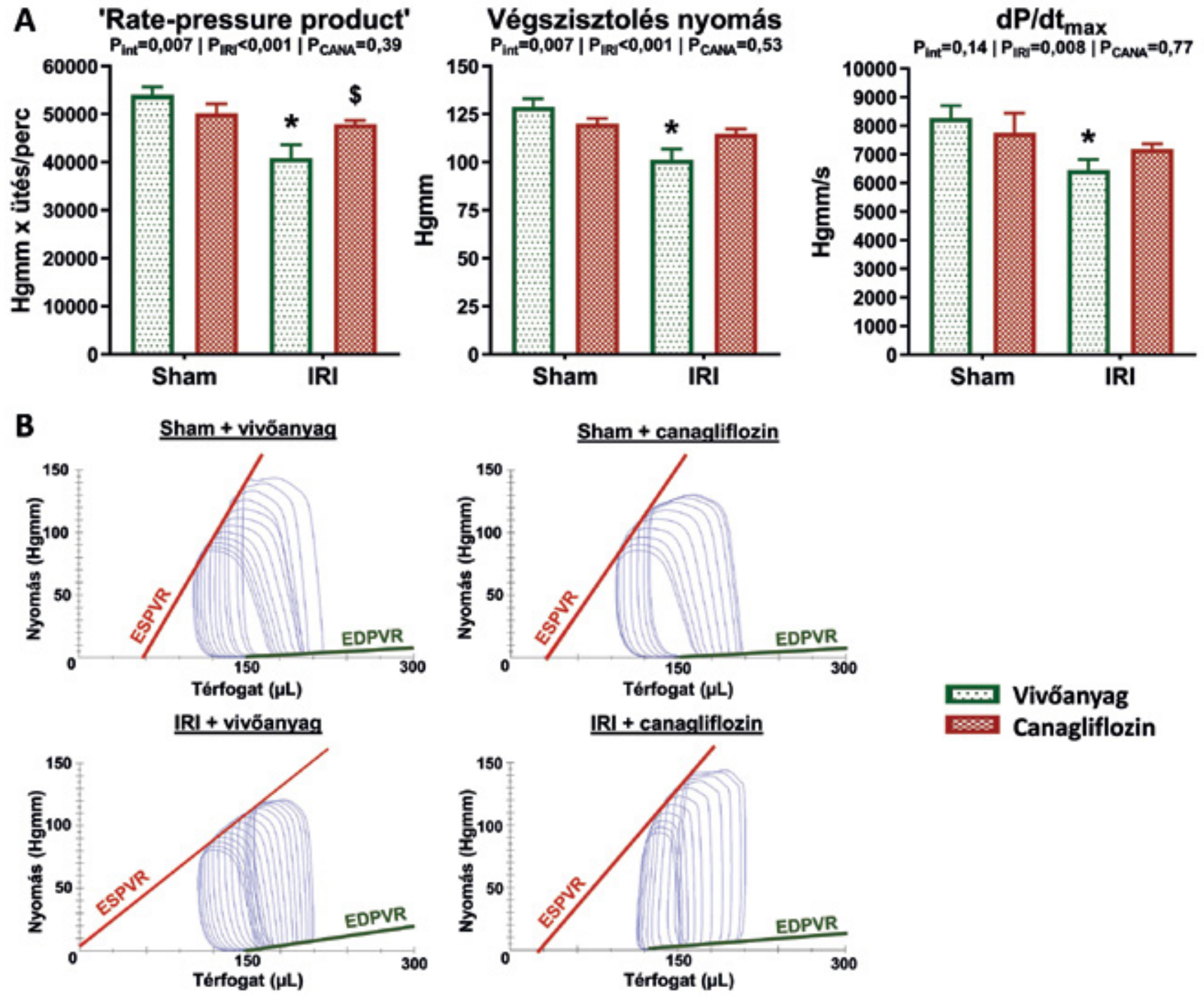

2. ÁBRA. In vivo bal kamrai (BK) nyomás-térfogat (PV) analízis. A: Elő- és utóterheléstől függő BK-i szisztolés paraméterek. B: Reprezentatív PV-hurkok egy-egy állatból a csoportoknak megfelelően, amelyeket a vena cava inferior ideiglenes okklúziója során nyertünk 

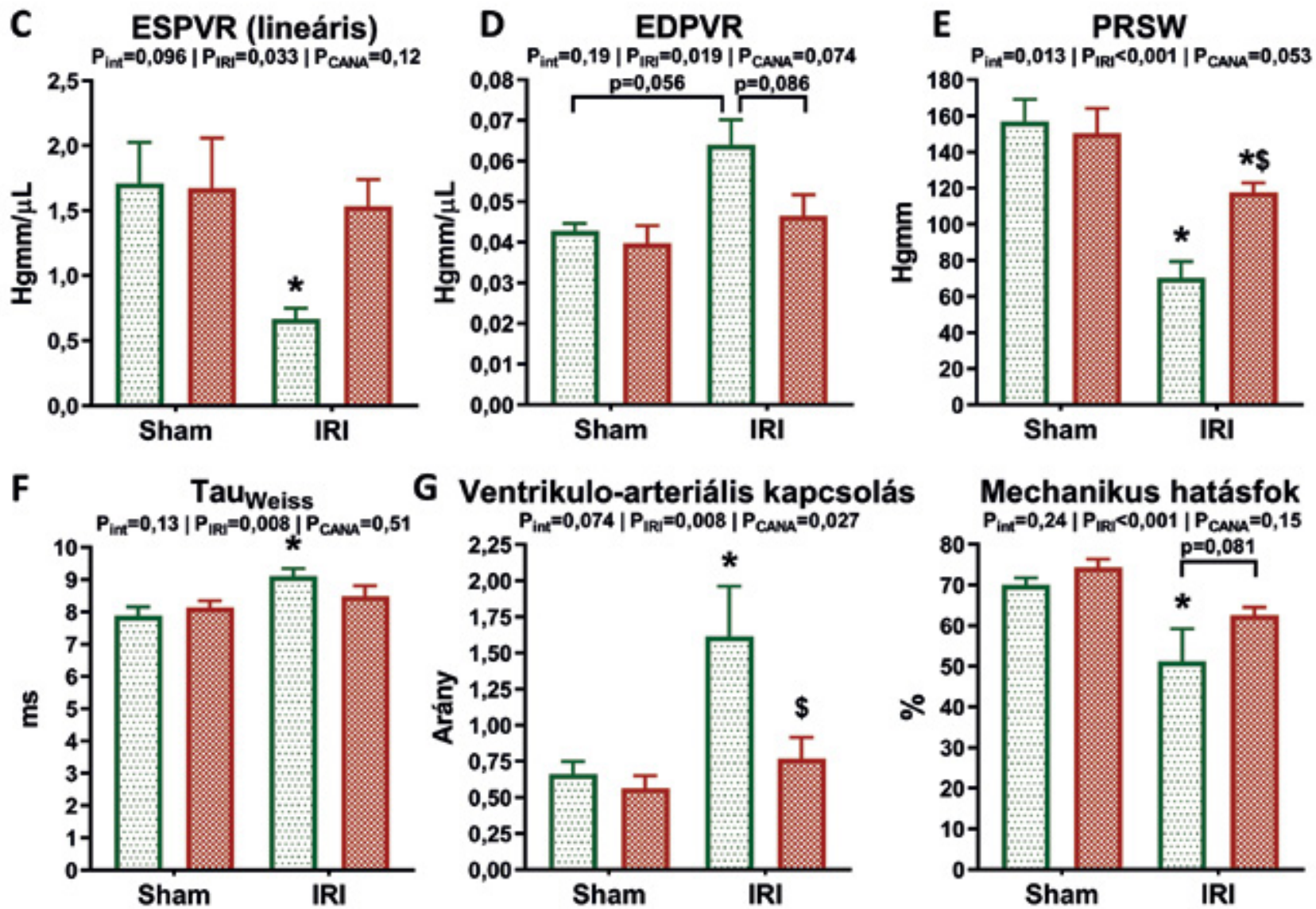

2. ÁBRA. C, E: Elő- és utóterheléstől független BK-i kontraktilitás paraméterek. D, F: BK-i diasztolés paraméterek. G: Mechanoenergetikai paraméterek. A kétutas varianciaanalízis (ANOVA) p-értékeit az alábbi két faktorral: iszkémia-reperfúziós károsodás $\left(P_{I R}\right)$ és canagliflozinkezelés $\left(P_{\text {CANA }}\right)$, illetve ezek interakcióját $\left(P_{\text {int }}\right)$ az ábracímek alatt tüntettük fel. A Tukey post-hoc tesztek eredményét az alábbi módon jelöltük: * $p<0,05$ vs. Sham + vivőanyag; ${ }^{\$} p<0,05$ vs. IRI + vivőanyag

A canagliflozin befolyásolta a kardioprotektív jelátviteli mediátorok foszforilációját A canagliflozinnak jelentös $\left(P_{\text {CANA }}<0,001\right)$ hatása volt az AMPK foszforilációjára a Thr172 aktivációs helyen, az IR-károsodástól függetlenül $\left(\mathrm{p}_{\text {int }}=0,11\right)$ (3. $A$ ábra). A downstream ACC-enzim AMPK specifikus Ser79 gátlóhelyén történö foszforilációja is szignifikánsan $\left(p_{\text {CANA }}=0,004\right)$ változott, amely jelentősen $(p=0,025)$ nagyobb mértékủnek adódott a kezelt infarktusos állatokban a vivőanyaghoz képest (3. $B$ ábra). Utóbbi az AMPK fokozott aktivációjára utal infarktusos patkányokban. Az eNOS foszforilációja a Ser1177 helyen elengedhetetlen a nitrogén-monoxid (NO) termelődéséhez (13). A canagliflozinkezelés jelentősen $\left(p_{\mathrm{CANA}}=0,013\right)$ befolyásolta az eNOS foszforilációját, IR-károsodástól függetlenül $\left(p_{\text {int }}=0,88\right)$ (3. $C$ ábra). A miokardiális IR-károsodás jelentős $\left(\mathrm{p}_{\mathrm{IRI}}<0,001\right)$ negatív hatással bírt az eNOS foszforilációjára, amely lényegesen $(p<0,001)$ alacsonyabbnak bizonyult a vivőanyaggal kezelt infarktusos csoportban az áloperált patkányokhoz képest (3. $C$ ábra). A canagliflozin viszont megörizte az eNOS foszforilációját (3. C ábra), utalva ezzel a megtartott NO-képződésre.

A canagliflozinnal kezelt infarktusos patkányokban az ismert kardioprotektív mediátor Akt foszforilációjának mértéke jelentősen $(p=0,024)$ magasabb volt az áloperált egyedekhez képest (3. $D$ ábra).

\section{A canagliflozin csökkentette az apoptoti- kus és a nitro-oxidatív stressz-markerek expresszióját}

A proapoptotikus Bax és az antiapoptotikus Bcl-2 miokardiális relatív mRNS és fehérje-expressziójának aránya jelentősen $(p<0,05)$ emelkedett a vivőanyaggal kezelt infarktusos csoportban az áloperált csoporthoz képest (4. A ábra). Ezt a canagliflozinkezelés megelőzte mRNS-szinten (4. A ábra), míg fehérjeexpressziós szinten a $\mathrm{Bax} / \mathrm{Bcl}-2$ arányt jelentősen $(\mathrm{p}=0,014)$ csökkentette (4. A ábra). Ez IR-károsodásra specifikus hatásnak bizonyult $\left(p_{\text {int }}=0,009\right)$.

A canagliflozinkezelés csökkentette $\left(p_{\text {CANA }}<0,05\right)$ a nitro-oxidatív stresszel összefüggő gének ( $p 47^{\text {phox }}$, 


\section{Wivon Vivanyag Canagliflozin}

A p-AMPK (Thr172)/AMPK
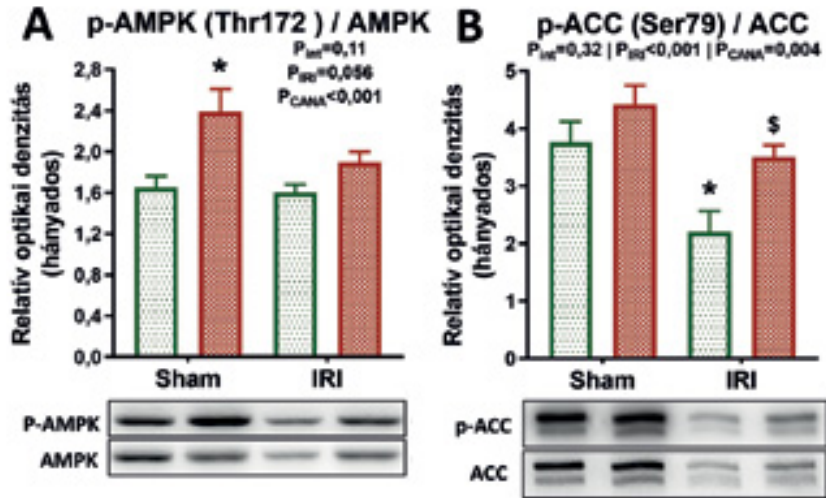
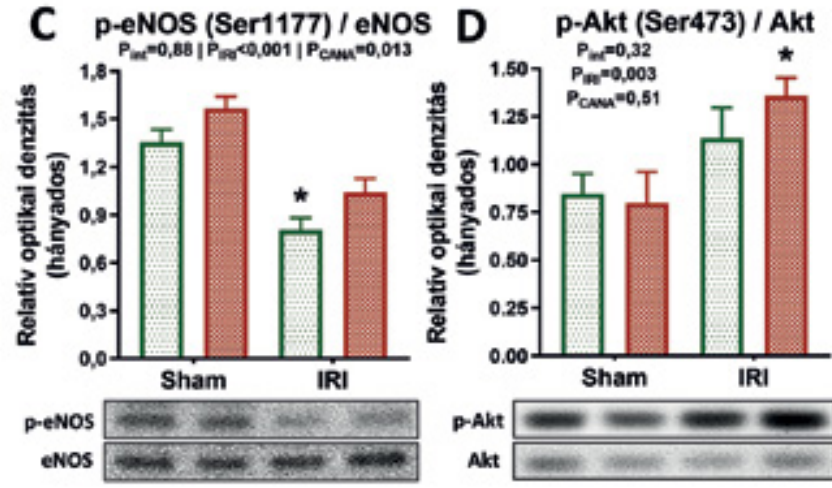

3. ÁBRA. A canagliflozinkezelés hatása kardioprotektív mediátorok foszforilációjára. A foszforilált fehérjék optikai denzitását a teljes fehérje optikai denzitására normalizáltuk. A kétutas varianciaanalízis (ANOVA) p-értékeit az alábbi két faktorral: iszkémia-reperfúziós károsodás $\left(P_{\mathbb{R}}\right)$ és canagliflozinkezelés $\left(P_{C A N A}\right)$, illetve ezek interakcióját $\left(P_{\text {int }}\right)$ az ábracímek alatt tüntettük fel. $A$ Tukey post-hoc tesztek eredményét az alábbi módon jelöltük: ${ }^{\star} p<0,05$ vs. Sham + vivőanyag; ${ }^{\$} p<0,05$ vs. IRI + vivőanyag

SOD2, kataláz) mRNS expresszióját (4. B ábra), IR-károsodástól függetlenül. Továbbá, a canagliflozinnal való kezelés jelentősen $(p=0,037)$ csökkentette a miokardiális HNE-immunreaktivitást infarktusos állatokban a vivőanyag-kezeléshez képest (4. C ábra).

A canagliflozin elöinkubáció fokozta az endothelfüggó vazorelaxációt aortagyứrúkben Áloperált állatokban a vivőanyaghoz képest a canagliflozin enyhén csökkentette a BK-i végszisztolés nyomást és az artériás elasztanciát in vivo (5. $A$ ábra). Egészséges patkányokból származó aortagyűrűkön végzett in vitro szervfürdős kísérleteink szerint a canagliflozinnal való előinkubáció jelentősen fokozta az aortagyürük érzékenységét $\mathrm{ACh}$-indukálta vazorelaxációra (pD2 [ACh], $p=0,006)$, valamint növelte a maximális vazorelaxáció mértékét $\left(R_{\max }[A C h], p=0,036\right)$ (5. $B$ ábra) a vivőanyaghoz képest, amely fokozott endothelfüggő, nitrogén-monoxid (NO)-mediálta vazorelaxációra utal. A canagliflozin nem volt hatással a nem endothelfüggő vazorelaxációra (5. C ábra).

\section{A canagliflozin nem befolyásolta a glükóz- szintet és egyéb laborparamétereket}

A canagliflozinnak normoglykaemiás patkányokban nem volt hatása a vér- és vizelet glükózszintjére. A szérum- és vizeletmarkerek alapján a kezelés nem okozott máj- vagy vesetoxicitást.

\section{Megbeszélés}

Elsőként mutattuk be, hogy az iszkémia beállta után intravénásan adott SGLT2-gátló canagliflozin nem di- abéteszes patkányokban kivédi a miokardiális IR-károsodást. A canagliflozin növelte a kardioprotektív mediátorok foszforilációját, miközben csökkentette az apoptotikus és nitrooxidatív stresszmarkerek expreszszióját így megelőzte az IR-károsodást követő BK-i szisztolés és diasztolés diszfunkció kialakulását. A gyógyszer enyhén csökkentette a vérnyomást és a BK-i utóterhelést in vivo, ezzel összhangban fokozta az endothelfüggő vazorelaxációt aortagyürükben in vitro.

Az SGLT2-gátlók antidiabetikus hatásának központi mechanizmusa a vese proximális kanyarulatos csatornájában történő glükózvisszaszívás gátlása. Braunwald szerint (5) a vesében történő SGLT2-gátlás nem ad teljes körü magyarázatot az SGLT2-gátlók klinikai vizsgálatokban megfigyelt nagymértékü kardiovaszkuláris védőhatására. A CANVAS Program klinikai vizsgálatban a canagliflozinkezelés hatására korán szétváló eseménygörbék és drasztikus szívelégtelenség miatti hospitalizációcsökkenés (2) (föleg eleve szívelégtelen betegekben) (3) azt sugallják, hogy a canagliflozin kardioprotektív hatása részben független lehet antidiabetikus hatásától annak ellenére, hogy az SGLT2 mRNS-és fehérje-expressziója az emberi szívben elhanyagolható (14). Ez lehetséges off-target hatásra utal.

Korábbi preklinikai tanulmányok szerint a canagliflozin erősen aktiválja az AMPK-t tumorsejtekben (15), egér hepatocytákban (6), és humán endothelsejtekben (16). Ismert, hogy az AMPK farmakológiai aktivációja kivédi a miokardiális IR-károsodást nem diabéteszes (17) és diabéteszes (18) egerekben, amelyet az eNOS megnövekedett foszforilációja közvetít. Ezen korábbi eredményekkel összhangban jelen tanulmányunkban bemutattuk, hogy canagliflozin iszkémia kialakulása utáni (tehát klinikailag releváns) intravénás beadása növelte az AMPK aktivációját in vivo, továbbá megelőzte az eNOS 

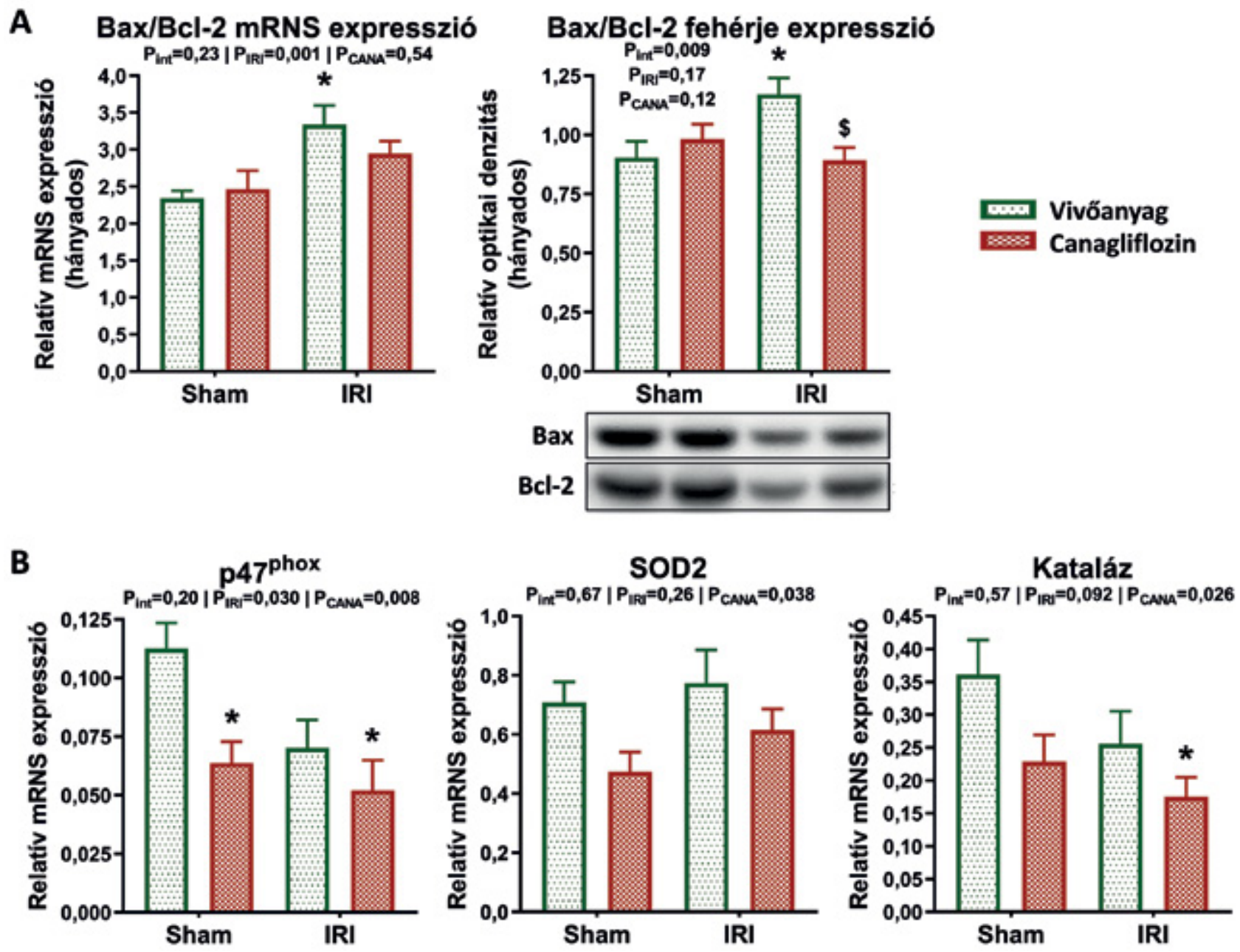

C
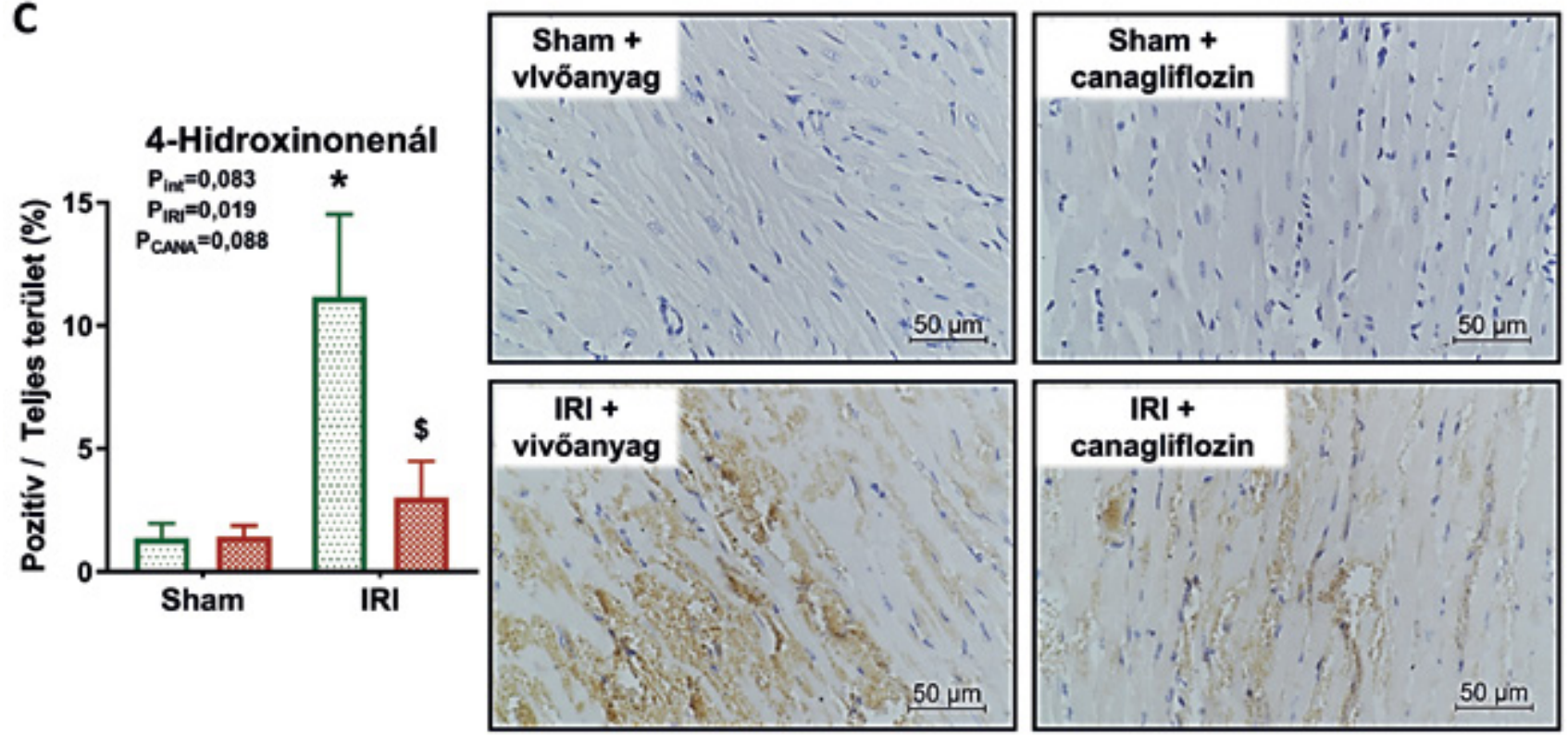

4. ÁBRA. Canagliflozin hatása apoptózis és nitro-oxidatív stresszmarkerekre. A: Bax/Bcl-2 mRNS-expresszió és fehérjeexpreszszió. B: Nitro-oxidatív stresszmarkerek mRNS expressziója RPL27-re normalizálva. C: A myocardium 4-hidroxinonenál (HNE) tartalmának kvantifikációja és reprezentatív metszetek egy-egy állat szívéből a csoportoknak megfelelően. A kétutas varianciaanalízis (ANOVA) p-értékeit az alábbi két faktorral: iszkémia-reperfúziós károsodás (PIRI) és canagliflozinkezelés (PCANA), illetve ezek interakcióját $\left(P_{\text {int }}\right)$ az ábracímek alatt tüntettük fel. A Tukey post-hoc tesztek eredményét az alábbi módon jelöltük: ${ }^{*} \mathrm{p}<0,05$ vs. Sham + vivőanyag; ${ }^{\$} \mathrm{p}<0,05$ vs. IRI + vivőanyag 


\section{A Végszisztolés nyomás}

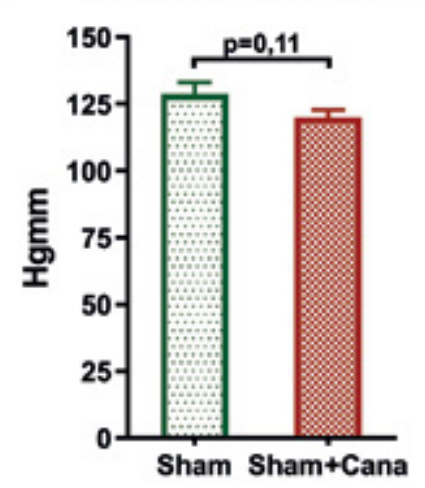

B Endothelfüggõ vazorelaxáció

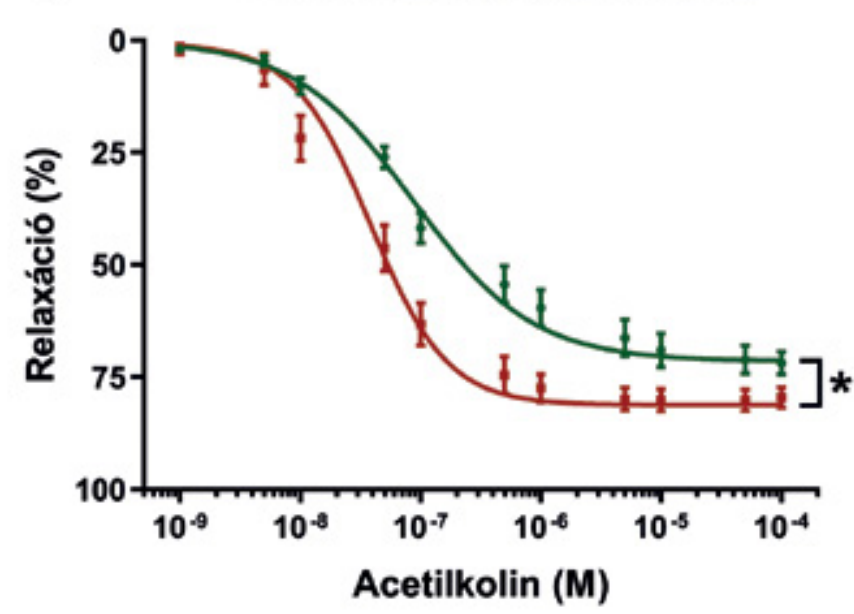

C Nem endothelfüggõ vazorelaxáció

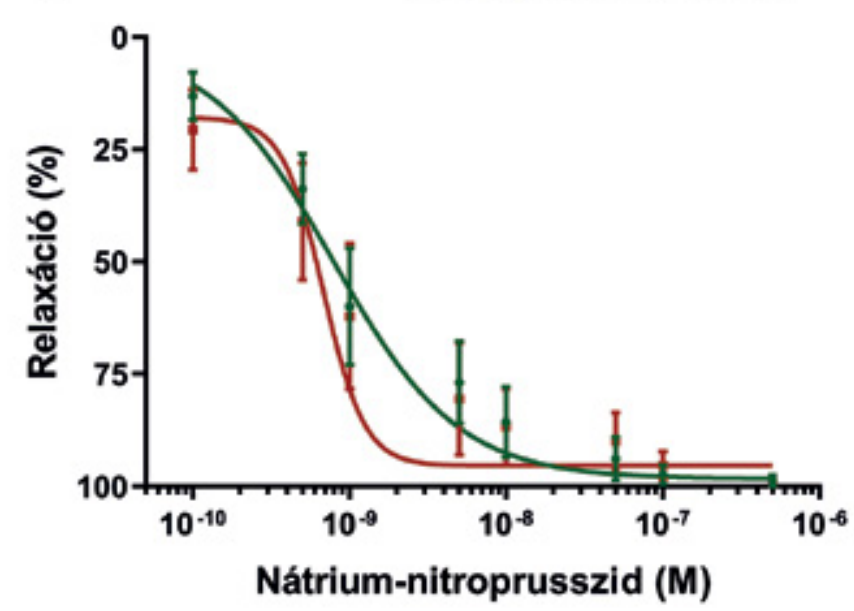

\section{Artériás elasztancia}

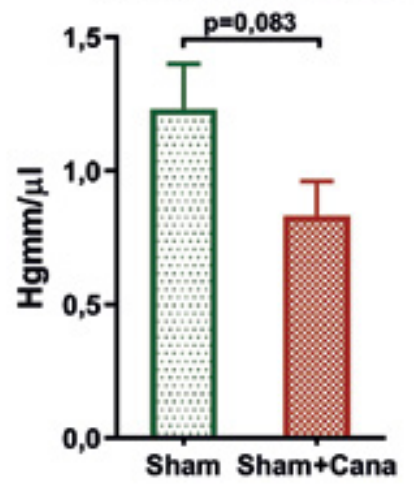

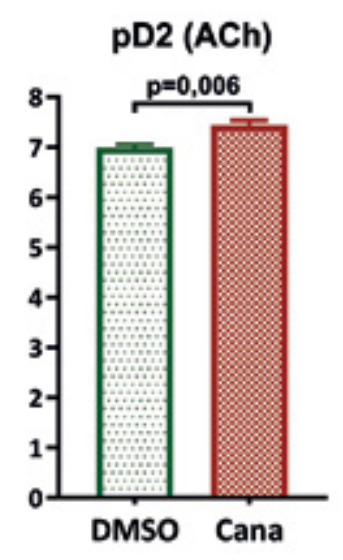
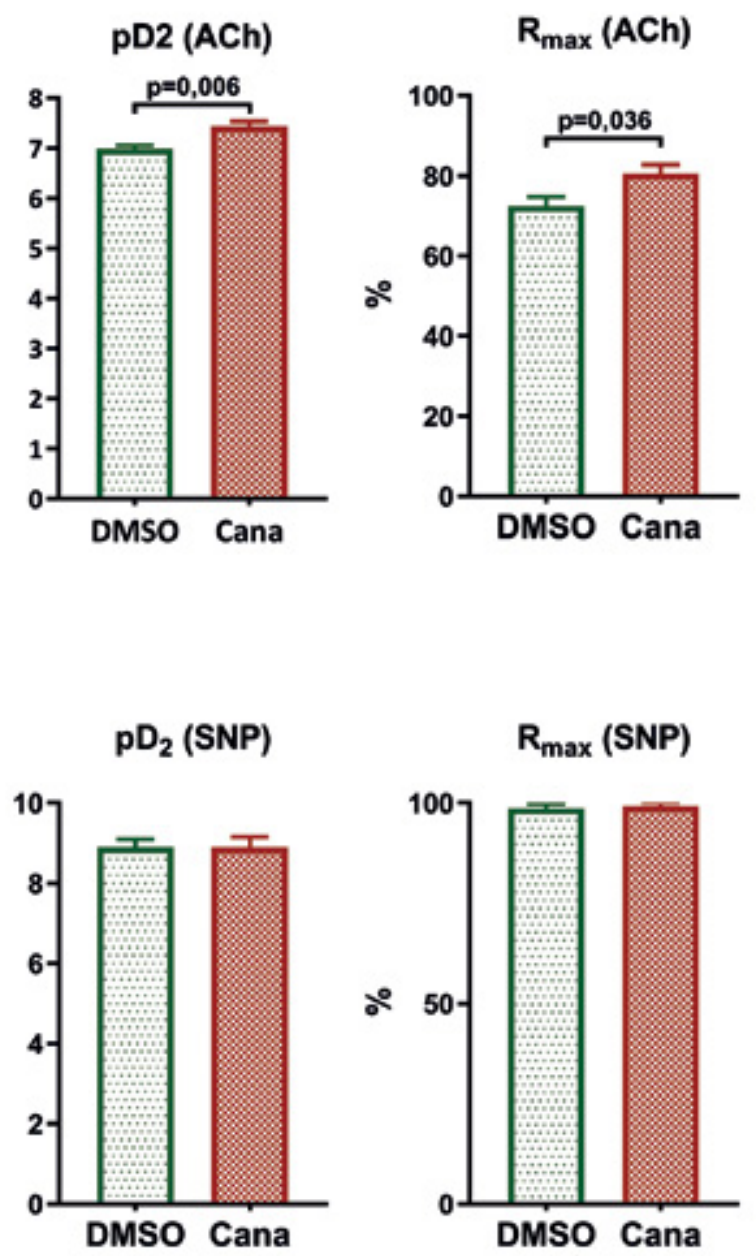

5. ÁBRA. A canagliflozin vérnyomásra és izolált aortagyűrükre kifejtett hatása. A: Egészséges, áloperált állatokban mért végszisztolés nyomás és artériás elasztancia. B: A canagliflozin hatása az endothelfüggő vazorelaxációra. C: A canagliflozin hatása az endothelfüggetlen vazorelaxációra. * $p<0,05$

foszforilációjának csökkenését IR-károsodást követöen, amely megtartott NO-jelátvitelre utal. Korábbi tanulmányok szerint a fenntartott NO-jelátvitel csökkenti az apoptózist, a miokardiális nitrooxidatív stresszt és a trombocitaaggregációt, megalapozva ezzel a mi- okardiális IR-károsodás elleni védelmet (19). Az Akt kulcsfontosságú IR-károsodás elleni mediátor, amely az eNOS-t az AMPK-val azonos helyen (Ser1177) foszforilálja (20). A canagliflozinnal kezelt infarktusos szívekben jelentősen fokozott Akt-foszforilációt találtunk 
az áloperált kontrollokhoz képest. Ismert, hogy mind az AMPK (21), mind az Akt (22) -aktiváció csökkenti a sejthalált miokardiális IR-károsodás során. Ezzel összhangban jelen kutatásunkban a canagliflozinkezelés csökkentette a Bax/Bcl-2 expressziós arányt, amely csökkent apoptotikus aktivitásra utal a LAD-lekötéstől disztálisan eső myocardiumban. Ennek megfelelően a canagliflozinnal kezelt infarktusos patkányokban az infarktusterület és a szérum-troponin-T-szintek 30\%-os csökkenését dokumentáltuk.

Az oxidatív stressz a miokardiális IR-károsodás egyik fő mediátora, amely hozzájárul a sejthalálhoz és növeli a szívizominfarktus kiterjedését (23). Tanulmányunkban a canagliflozinkezelés csökkentette az oxidatív stressz marker p47 ${ }^{\text {phox }}$, SOD2- és kataláz-enzimek expresszióját, egybevágóan egy korábbi kutatással, amelyben az AMPK farmakológiai aktivációja csökkentette ezen enzimek expresszióját a vesében IR-károsodást követően (24). A miokardiális IR-károsodással összefüggő oxidatív stressz során felhalmozódó reaktív oxigéngyökök fokozzák a lipidperoxidációt, amely során a legtoxikusabb aldehid végtermék, a HNE felhalmozódik. Ismert, hogy a myocardiumban a HNE megzavarja az enzimatikus és a mitokondriális folyamatokat és felhalmozódása negatív összefüggést mutat a miokardiális IR-károsodást követő funkcionális regeneráció mértékével (25). Jelen tanulmányunkban jelentősen alacsonyabb HNE immunreaktivitást dokumentáltunk a canagliflozinnal kezelt infarktusos szívekben a vivőanyaggal kezeltekhez képest, ezzel párhuzamosan javult a BK-i funkcionális regeneráció.

Részletes szívfunkciós analízisünk szerint egyetlen intravénás canagliflozin bólus klinikailag releváns módon (vagyis iszkémia beállta után) adva lényegesen javította a myocardium regenerációját IR-károsodást követően, ahogy ezt a jelentősen magasabb RPP, BK-i végszisztolés nyomás és $\mathrm{dP} / \mathrm{dt}_{\text {max }}$ is bizonyítja. Eredményeink egybevágnak egy korábbi tanulmányéval, amelyben egy farmakológiai AMPK-aktivátor javította a BK-i funkcionális regenerációt IR-károsodás során (17). Az ESPVR és a PRSW kontraktilitás paraméterek jelentős javulást mutattak a canagliflozinnal kezelt miokardiális infarktust szenvedett patkányokban, ami jól jelzi, hogy a canagliflozin kivédte a szisztolés diszfunkció kialakulását. Továbbá a kezelés jelentősen javította a VAC-ot, amely a BK-i kontraktilitás és artériás utóterhelés közötti fiziológiásabb kapcsolásra utal. Ezen felül a canagliflozin csökkentette a BK-i falmerevséget (EDPVR) és az aktív relaxáció időkonstansát (Tau Weiss $_{\text {), }}$, azaz hatékonyan védte ki a diasztolés diszfunkció kialakulását. Ezzel összhangban a canagliflozinkezelés megelőzte a BK-i mechanikus hatásfok romlását, ami azt mutatja, hogy adott perctérfogat fenntartásához a szívnek kevesebb egységnyi oxigénre volt szüksége a kezelés hatására.

$A z$ akut canagliflozinkezelés enyhén csökkentette a szisztolés vérnyomást és az utóterhelést anélkül, hogy reflex tachycardiát okozott volna. A szer klinikai vizsgálatokban már a korai szakban enyhén csökkentette a szisztolés vérnyomást 2-es típusú cukorbetegekben $(2,26)$. Korábbi kísérletes tanulmányok szerint a canagliflozin előinkubáció fokozta a vazorelaxációt diabéteszes egerekből származó pulmonális érgyűrűkön (8) és növelte az ACh-ra adott vazorelaxáns hatást aortagyűrükön hyperglykaemiás körülmények között (9). Ex vivo, nem diabéteszes egérszívekben a canagliflozin csökkentette a perfúziós nyomást, ami a koronáriák fokozott dilatációjára utal (7). Jelen eredményeink szerint a nem diabéteszes patkányokból származó aortagyűrük előkezelése klinikailag releváns koncentrációjú canagliflozinnal növelte az ACh-ra adott vazorelaxáció mértékét és az aortagyürük maximális relaxációját. Ez a canagliflozin antidiabetikus hatásától független, direkt vazorelaxáns hatás, amely magyarázattal szolgálhat a szer in vivo, egészséges patkányokban megfigyelt enyhe utóterhelést csökkentő hatására. A canagliflozin az infarktusterületet és nitrooxidatív stresszt csökkentő hatásának nagy részét a reperfúzió során a rizikóterületre bemosódva lokálisan fejthette ki. Azonban a canagliflozin direkt vazorelaxáns hatásából adódóan nem zárható ki, hogy az utóterhelés enyhe csökkentése, így a BK tehermentesítése az IR során hozzájárulhatott ezen kedvező hatásokhoz.

\section{Következtetések}

Összességében elmondhatjuk, hogy a canagliflozin klinikai tanulmányokban megfigyelt, 2-es típusú diabéteszes egyénekben kifejtett nagymértékü kardiovaszkuláris védőhatása az antidiabetikus hatástól részben függetlennek tűnik, mivel a canagliflozin fokozta a kardioprotektív jelátvitelt és az endothelfüggő vazorelaxációt nem diabéteszes patkányokban. Ennek megfelelően a canagliflozin kivédte a miokardiális IR-károsodást és enyhítette a szisztolés és diasztolés diszfunkciót tanulmányunkban.

\section{Támogatás}

A kutatást Baden-Württemberg német szövetségi tartomány, továbbá az Emberi Erőforrások Minisztériuma (Új Nemzeti Kiválósági Program, ÚNKP-18-2-I-SE-100) és a Stephen W. Kuffler Alapítvány támogatta. Jelen tanulmány megjelenését a Nemzeti Kutatási, Fejlesztési és Innovációs Hivatal támogatta (NKFIA; NVKP_16-12016-0017 Nemzeti Szívprogram). A kutatást az Innovációs és Technológiai Minisztérium Tématerületi Kiválósági Programja (2020-4.1.1.-TKP2020) finanszírozta, a Semmelweis Egyetem Terápiás Fejlesztés és Bioimaging tématerületi programjai keretében.

\section{Nyilatkozat}

A szerzők kijelentik, hogy az eredeti közlemény megírásával kapcsolatban nem áll fenn velük szem- 


\section{ben pénzügyi vagy egyéb lényeges összeütközés, összeférhetetlenségi ok, amely befolyásolhatja a közleményben bemutatott eredményeket, az abból levont következtetéseket vagy azok értelmezését.}

Irodalom

1. Zinman B, Wanner C, Lachin JM, et al. Empagliflozin, Cardiovascular Outcomes, and Mortality in Type 2 Diabetes. N Engl J Med 2015; 2117-28. https://doi.org/10.1056/NEJMoa1504720

2. Neal B, Perkovic V, Mahaffey KW, et al. Canagliflozin and Cardiovascular and Renal Events in Type 2 Diabetes. N Engl J Med 2017; 644-57. https://doi.org/10.1056/NEJMoa1611925

3. Mahaffey KW, Neal B, Perkovic V, et al. Canagliflozin for Primary and Secondary Prevention of Cardiovascular Events: Results From the CANVAS Program (Canagliflozin Cardiovascular Assessment Study). Circulation 2018; 323-34.

https://doi.org/10.1161/CIRCULATIONAHA.117.032038

4. Bell RM, Yellon DM. SGLT2 inhibitors: hypotheses on the mechanism of cardiovascular protection. Lancet Diabetes Endocrinol 2018; 435-7. https://doi.org/10.1016/S2213-8587(17)30314-5

5. Zelniker TA, Braunwald E. Cardiac and Renal Effects of SodiumGlucose Co-Transporter 2 Inhibitors in Diabetes: JACC State-of-theArt Review. J Am Coll Cardiol 2018.

https://doi.org/10.1016/j.jacc.2018.06.040

6. Hawley SA, Ford RJ, Smith BK, et al. The Na+/Glucose Cotransporter Inhibitor Canagliflozin Activates AMPK by Inhibiting Mitochondrial Function and Increasing Cellular AMP Levels. Diabetes 2016; 2784-94. https://doi.org/10.2337/db16-0058

7. Uthman L, Baartscheer A, Bleijlevens B, et al. Class effects of SGLT2 inhibitors in mouse cardiomyocytes and hearts: inhibition of $\mathrm{Na}(+) / \mathrm{H}(+)$ exchanger, lowering of cytosolic $\mathrm{Na}(+)$ and vasodilation. Diabetologia 2018; 722-6.

https://doi.org/10.1007/s00125-017-4509-7

8. Han Y, Cho YE, Ayon R, et al. SGLT inhibitors attenuate NOdependent vascular relaxation in the pulmonary artery but not in the coronary artery. Am J Physiol Lung Cell Mol Physiol 2015; L102736. https://doi.org/10.1152/ajplung.00167.2015

9. El-Daly M, Pulakazhi Venu VK, Saifeddine M, et al. Hyperglycaemic impairment of PAR2-mediated vasodilation: Prevention by inhibition of aortic endothelial sodium-glucose-co-Transporter-2 and minimizing oxidative stress. Vascul Pharmacol 2018; 56-71.

https://doi.org/10.1016/j.vph.2018.06.006

10. Devineni D, Murphy J, Wang SS, et al. Absolute oral bioavailability and pharmacokinetics of canagliflozin: A microdose study in healthy participants. Clin Pharmacol Drug Dev 2015; 295-304. https://doi.org/10.1002/cpdd.162

11. Radovits T, Olah A, Lux A, et al. Rat model of exercise-induced cardiac hypertrophy: hemodynamic characterization using left ventricular pressure-volume analysis. Am J Physiol Heart Circ Physiol 2013; H124-34. https://doi.org/10.1152/ajpheart.00108.2013

12. Korkmaz S, Radovits T, Barnucz E, et al. Dose-dependent effects of a selective phosphodiesterase-5-inhibitor on endothelial dysfunction induced by peroxynitrite in rat aorta. Eur $\mathrm{J}$ Pharmacol
2009; 155-62. https://doi.org/10.1016/i.ejphar.2009.05.020

13. Chen ZP, Mitchelhill KI, Michell BJ, et al. AMP-activated protein kinase phosphorylation of endothelial NO synthase. FEBS Lett 1999; 285-9. https://doi.org/10.1016/s0014-5793(98)01705-0

14. Chen J, Williams S, Ho S, et al. Quantitative PCR tissue expression profiling of the human SGLT2 gene and related family members. Diabetes Ther 2010; 57-92.

https://doi.org/10.1007/s13300-010-0006-4

15. Villani LA, Smith BK, Marcinko K, et al. The diabetes medication Canagliflozin reduces cancer cell proliferation by inhibiting mitochondrial complex-I supported respiration. Mol Metab 2016; 1048-56. https://doi.org/10.1016/j.molmet.2016.08.014

16. Mancini SJ, Boyd D, Katwan OJ, et al. Canagliflozin inhibits interleukin-1beta-stimulated cytokine and chemokine secretion in vascular endothelial cells by AMP-activated protein kinase-dependent and -independent mechanisms. Sci Rep 2018; 5276.

https://doi.org/10.1038/s41598-018-23420-4

17. Kim AS, Miller EJ, Wright TM, et al. A small molecule AMPK activator protects the heart against ischemia-reperfusion injury. $\mathrm{J} \mathrm{Mo}$ Cell Cardiol 2011; 24-32.

https://doi.org/10.1016/j.yjmcc.2011.03.003

18. Calvert JW, Gundewar S, Jha S, et al. Acute metformin therapy confers cardioprotection against myocardial infarction via AMPKeNOS-mediated signaling. Diabetes 2008; 696-705.

https://doi.org/10.2337/db07-1098

19. Lefer AM. Attenuation of myocardial ischemia-reperfusion injury with nitric oxide replacement therapy. Ann Thorac Surg 1995; 84751. https://doi.org/10.1016/0003-4975(95)00423-I

20. Zou MH, Hou XY, Shi CM, et al. Modulation by peroxynitrite of Akt- and AMP-activated kinase-dependent Ser1179 phosphorylation of endothelial nitric oxide synthase. J Biol Chem 2002; 32552-7. https://doi.org/10.1074/jbc.M204512200

21. Shibata R, Sato K, Pimentel DR, et al. Adiponectin protects against myocardial ischemia-reperfusion injury through AMPK- and COX-2-dependent mechanisms. Nat Med 2005; 1096-103.

https://doi.org/10.1038/nm1295

22. Fujio $Y$, Nguyen T, Wencker D, et al. Akt promotes survival of cardiomyocytes in vitro and protects against ischemia-reperfusion injury in mouse heart. Circulation 2000; 660-7.

23. Dhalla NS, Elmoselhi AB, Hata T, et al. Status of myocardial antioxidants in ischemia-reperfusion injury. Cardiovasc Res 2000; 446-56.

24. Lempiainen J, Finckenberg $P$, Levijoki J, et al. AMPK activator AICAR ameliorates ischaemia reperfusion injury in the rat kidney. $\mathrm{Br}$ J Pharmacol 2012; 1905-15.

https://doi.org/10.1111/j.1476-5381.2012.01895.x

25. Blasig IE, Grune T, Schonheit K, et al. 4-Hydroxynonenal, a novel indicator of lipid peroxidation for reperfusion injury of the myocardium. Am J Physiol 1995; H14-22.

https://doi.org/10.1152/ajpheart.1995.269.1.H14

26. Pfeifer M, Townsend RR, Davies MJ, et al. Effects of canagliflozin, a sodium glucose co-transporter 2 inhibitor, on blood pressure and markers of arterial stiffness in patients with type 2 diabetes mellitus: a post hoc analysis. Cardiovasc Diabetol 2017; 29. https://doi.org/10.1186/s12933-017-0511-0 